Olga Cyrek*

Uniwersytet Rzeszowski

\title{
NOWOŻYTNE IKONY BIZANTYJSKIE I RUSKIE Z SYMBOLICZNYMI WIZERUNKAMI JEZUSA CHRYSTUSA. KANON IKONOGRAFICZNY I WYJAŚNIENIE TEOLOGICZNE
}

Stowa kluczowe

symbolizm, ikonografia, sztuka bizantyjska, chrystologia, teologia

Treść

I. Chrystus jako Przedwieczne Słowo ukazany pod postacią Dzieciątka na ikonie Bogurodzicy „Znaku”

II. Chrystus Baranek Boży (Cząstka Prosfory)

III., Czuwające Oko Chrystusa”

IV. Wizerunek Syna Bożego w wyobrażeniach Trójcy Świętej

1. Trójca Święta typu Starotestamentowego

2. Trójca Święta typu Nowotestamentowego

V. Wyobrażenia Chrystusa pod postacią anioła

1. Chrystus Święte Milczenie

2. Chrystus ukrzyżowany serafin (Dusza Chrystusa)

3. Ikona Sofii - Mądrości Bożej

Już od początku istnienia sztuki ikonopisania zdawano sobie sprawę z faktu, że wszystkie tego typu obrazy sakralne są w swej podstawie chrystologiczne ${ }^{1}$, gdyż zawsze odnoszą się pośrednio czy też bezpośrednio do tajemnicy Wcielenia Drugiej

* Olga Cyrek, doktor nauk humanistycznych w zakresie historii, pracownik naukowy Uniwersytetu Rzeszowskiego.

1 Na temat chrystologii zob. J. Bujak, ,On jest obrazem Boga niewidzialnego” (Kol 1, 15). Wprowadzenie do chrystologii, Szczecin 2011; G. O'Collins, Chrystologia. Jezus Chrystus w ujęciu biblijnym, historycznym i systematycznym, Kraków 2008; H. Langkammer, Chrystologia, w: Encyklopedia Katolicka, t. III, kol. 305; G. L. Müller, Chrystologia: nauka o Jezusie Chrystusie, Kraków 1998. 
Osoby Trójcy Świętej². Każda ikona jest chrystocentryczna, ponieważ niezależnie od tego, kogo przedstawia, czy to Bogurodzicę czy świętych, zawsze w jakimś stopniu odzwierciedla Wcielone Słowo Boga ${ }^{3}$. Dogmat o Wcieleniu Syna stał się też podstawą istnienia każdej ikony. Chrystus uniżył się do tego stopnia, że wcielił się i przyjął ludzkie ciało, nie wyniszczając przy tym swej boskości ${ }^{4}$. Dogmat o Jego dwóch naturach został określony na Soborze Chalcedońskim w 451 rokus, a to połączenie Bóstwa z ludzką naturą ujawnia się na każdej ikonie wyobrażającej Chrystusa. Do dogmatu Wcielenia odniósł się później także Sobór w Nicei ${ }^{6}$ w 787 roku, który podkreślił fakt wcielenia się Syna Bożego w ludzkie ciało, co stanowiło wystarczający argument potwierdzający konieczność istnienia ikony?

Na początku istnienia chrześcijaństwa $\mathrm{z}$ uwagi na powtarzające się prześladowania religijne, które mogły przyczynić się do profanacji wizerunków Zbawiciela unikano wyobrażeń dosłownych i bezpośrednio ukazujących Jezusa Chrystusa ${ }^{8}$.

2 Wcielenie (łac. incarnatio) - to termin teologiczny, określający przyjęcie przez Drugą Osobę Trójcy Świętej, czyli Syna Bożego ludzkiego ciała, a tym samym ludzkiej natury poprzez narodzenie z Dziewicy. Dogmat o Wcieleniu potwierdził również sobór chalcedoński (451), gdzie stwierdzono zjednoczenie w jednej osobie Chrystusa dwóch natur: ludzkiej i boskiej (por. T. D. Łukaszuk, Ty jesteś Chrystus, Syn Boga Żywego. Dogmat chrystologiczny w ujęciu integralnym, Kraków 2000). Tajemnica Wcielenia stała się głównym argumentem wykorzystywanym przez apologetów kultu ikony, dla których stał się on podstawą istnienia obrazu sakralnego. Właśnie dzięki temu, że Chrystus wcielił się w ludzkie ciało, mógł być przedstawiany w sztuce. Zaprzeczanie możliwości przedstawiania Chrystusa na ikonach równało się z odrzuceniem Jego Wcielenia (por. S. Bułgakow, Ikona i kult ikony, Zarys dogmatyczny; thum. H. Paprocki, Bydgoszcz 2002, s. 14).

3 I. Jazykowa, Świat ikony, tłum. H. Paprocki, Warszawa 1998, s. 72 (por. G. Lange, Bild und Wort. Die katechetischen Funktionem des Bildes in der griechischen Theologie des sechsten bis neunten Jahrhunderts, Würzburg 1969).

4 List papieża Leona do Flawiana 4, Sobór chalcedoński (451), w: Dokumenty soborów powszechnych, t. I, oprac. A. Baron, H. Pietras, Kraków 2002, s. 202: Ingreditur ergo haec mondi infima filius dei de caelesti sede descendent et a paterna gloria non precedens novo ordine [...]; List Leona znajduje się też w: E. Schwarz, Acta Conciliorum Oecumenicorum (dalej: ACO), cz. 2, II, s. 24-33, Berolini et Lipsiae 1927-1932; ACO cz. 2, II, 1, 24-33; poprzednie thumaczenie polskie: K. Tomczak w: Leon Wielki, Mowy wybrane, POK 24, Poznań 1958, XXXVIII-XLIX; Definicja dogmatyczna zawarta jest w: ACO cz. 2, I, 2, 126-130 (greka); ACO cz. 2, III, 2, 134-138 (łacina); Kanony 1-28 zawarte są w: P. P. Joannou, Les canons des conciles oecuménoques, Pontifica commisione per la redazione del codice di diritto canonico orientalne, t. I/1, Grottaferrata - Roma 1962, s. 69-90 (greka).

5 List papieża Leona do Flawiana 4, Sobór chalcedoński (451), s. 202: [...] Qui enim verus est deus, idem verus est homo. [...] dum in invicem sunt et humilita hominis et altitudo deitatis. [...]

6 Wydania postanowień soboru w Nicei (787) zob. J. D. Mansi, Sacrorum Conciliorum Nova et Amplissima Collectio 13; reprint: Paris 1901, s. 373-380; 415 n; G. Alberigo, G. L. Rossetti, P. P. Joannou, C. Leopardi, P. Prodi, Conciliorum Oecumenicorum Decreta, Colonia 1991, s. 133-156; P. P. Joannou, Les canons des conciles oecumeniques, dz. cyt., s. 120-125.

7 Sobór nicejski II (787), Dekret wiary 13, w: Dokumenty soborów powszechnych, t. I, s. 337: [...] ad certitudinem verte et non secundum phantasiam Dei Verbi inhumanationis effectae [...].

8 Więcej na temat sztuki pierwszych chrześcijan, zob. E. Jastrzębowska, Sztuka wczesnochrześcijańska, Warszawa 1988; W. Mole, Sztuka starochrześcijańska, Warszawa 1994. 
Początkowo sztuka figuratywna operowała symbolami'; pierwsze z nich pochodzące z II i III w. wskazywały na Chrystusa jako Zbawiciela, a wśród nich wyróżniały się takie symbole jak: ryba ${ }^{10}$, baranek ${ }^{11}, \mathrm{krzyz}^{12} . \mathrm{Z}$ czasem pojawiła się konieczność ukazywania wyobrażeń figuratywnych, ale także jeszcze o symbolicznym znaczeniu. Przykładem może być wizerunek Hermesa Krioforosa - Dobrego Pasterza, ukazanego jako młodzieńca niosącego na barkach owieczkę, który w mentalności chrześcijańskiej oznaczał samego Chrystusa ${ }^{13}$.

Gdy chrześcijaństwo uzyskało status religii państwowej również artyści uzyskali możliwość swobodnego wyrażania się. To przyczyniło się do tego, że nie musieli już oni wtedy operować symbolami, aby zakryć przed odbiorcami prawdziwy sens swych dzieł. Symbolizm obecny w sztuce pierwszych chrześcijan nie zaspokajał już potrzeb ludzi nowych czasów, kiedy liturgia rozbudowała się i wymagała bogatszej oprawy także artystycznej ${ }^{14}$. Zaistniała konieczność dosłownego wyrażania treści dogmatycznych oraz bezpośredniego ukazywania Chrystusa w takiej postaci, w jakiej ujawnił się On ludzkim oczom. Istotne w tym wypadku były postanowienia Soboru Trullańskiego z 692 r (piąto-szóstego), który w kanonie 82 zawarł następujący tekst: „Dlatego, aby i w sztuce malarstwa oczom wszystkich przedkładane było doskonałe, nakazujemy, aby dotąd wizerunek Baranka, Chrystusa Boga

9 Por. B. Degórski, Materialne znaki i symbole w pierwszych wiekach Kościoła, w: Chrystus wybawiający. Teologia świętych obrazów, red. A. A. Napiórkowski, Kraków 2003, s. 53. Definicja: symbol (gr. sýmbolon) - to obrazowy (namacalny) odpowiednik niewidzialnego abstrakcyjnego pojęcia. Można powiedzieć, iż jest to umowny znak wskazujący na inną niewyobrażalną rzeczywistość. Różni się on od przeciętnych znaków tym, że przeważnie posiada uniwersalne przesłanie i związane jest ze światem duchowym. Natomiast typowe znaki są rozumiane tylko w określonej epoce historycznej i w danej grupie społecznej i są związane bardziej z rzeczywistością ziemską. Słowo „symbol” oznaczało początkowo jakiś niewielki przedmiot taki jak, np. pierścień czy też tabliczka z określonym napisem, czy prawną formułą. Taka rzecz była rozłamywana na dwie połówki przez osoby zawierające między sobą istotną umowę. Połówki te wskazywały też na silną więź łączącą przyjaciół, którzy gdy się rozstawali, to rozłamywali ważną dla nich rzecz na dwie połowy. Jednak powtórnie mogli oni je złączyć w jedną niepodzielną całość (gr. symballein). Symbol stanowi zatem znak dwóch części wzajemnie połączonych. Stąd też czasownik symbállo thumaczono jako „składam, łączę”. Nazwą sýmbolon określano także dokument, w którym zapisywano prawne zobowiązania. Także odnosiło się ono do wyznania wiary (credo) ustalonego na soborach (por. K. Onasch, A. Schnieper, Ikony. Fakty i legendy, thum. Z. Szanter, Warszawa 2007, s. 133).

10 B. Degórski, Materialne znaki i symbole w pierwszych wiekach Kościoła, dz. cyt., s. 53; I. Jazykowa, Świat ikony, dz. cyt., s. 72.

${ }_{11} \mathrm{Na}$ temat baranka, zob. H. Ły sy, Baranek paschalny-biblijny, starochrześcijański i wspótczesny symbol, w: Ad Christianorum unitatem fovendam: księga pamiątkowa dedykowana ks. abp. Alfonsowi Nossolowi, Opole 2007; H. Strąkowski, Chrystus - Baranek w Piśmie Świętym: studium z teologii biblijnej, Lublin 1961.

12 Na temat krzyża zob. A. Grün, Krzyż - symbol odkupionego człowieka, Kraków 1998.

13 W. Kurpik, Rozmyślając o genezie wizerunków Zbawiciela, w: Chrystus wybawiajacy, dz. cyt., s. 129; I. Jazykowa, Świat ikony, dz. cyt., s. 72.

14 A. A. Napiórkowski, Z historii teologii świętych obrazów, w: Chrystus wybawiający, dz. cyt., s. 15 . 
naszego, który gładzi grzechy świata, na ikonach zamiast starotestamentowego baranka przedstawiać w postaci ludzkiej, abyśmy w ten sposób rozmyślając nad pokorą Boga Słowa przypomnieli sobie Jego żywot w ciele, Jego Mękę i zbawczą śmierć"15. Skoro Chrystus przyjął widzialną postać, tak też mógł być ukazywany, a tworzenie wizerunków portretowych uznano za bardziej uzasadnione od symboli baranka obecnych w dawnej sztuce ${ }^{16}$. Widać więc, że wraz z rozwojem sztuki chrześcijanie odchodzili od przedstawień symbolicznych na korzyść dosłownych scen z Pisma Świętego. Jednak w czasach średniowiecznych i nowożytnych znów coraz częściej sięgano do symboli. Ta tendencja szczególnie była widoczna od XVI w. na Rusi.

Celem niniejszego artykułu jest właśnie opisanie kanonu ikonograficznego tych przedstawień Chrystusa, w których dopatrzeć się można wielu znaczeń symbolicznych. Nie chodzi tu jednak o wczesnochrześcijańskie proste przedstawienia, lecz o rozbudowane pod względem teologicznym ikony bizantyjskie i ruskie tworzone u progu czasów nowożytnych. Na ikonach tych Zbawiciel przybiera co prawda ludzką postać, jednak znajduje się w otoczeniu różnych kosmicznych atrybutów, lub też ukazany jest w takim kontekście, że całą scenę można interpretować w symboliczny sposób. Można nawet stwierdzić, że to właśnie symboliczne ikony w szczególny sposób ukazują nam zbawczą ekonomię Boga i Jego przedwieczny zamysł odkupienia ludzkości.

\section{CHRYSTUS JAKO PRZEDWIECZNE SŁOWO UKAZANY POD POSTACIĄ DZIECIĄTKA NA IKONIE BOGURODZICY „ZNAKU”}

Do symbolicznych przedstawień Chrystusa zaliczały się Jego wizerunki, na których występował on jako dziecko. Szczególnie dotyczyło to ikon maryjnych, z których tutaj omówiona zostanie ikona Matki Boskiej noszącej nazwę „Znamienije"17 lub Wcielenie.

Przecież tak naprawdę ekonomia zbawienia zapoczątkowana została na ziemi aktem Wcielenia, a zasadniczą rolę w nim odegrała Bogurodzica, w której łonie „Słowo ciałem się stało i zamieszkało między nami”"18. Dlatego też w kompozycji ikonograficznej „Znak” (gr. Semantron; ros. Znamienije) występującej tylko na Rusi, w centrum umieszczona jest nie tylko postać Theothokos przyjmującej postawę Orantki, ale także na jej piersi unosi się medalion, we wnętrzu którego

15 L. Uspienski, Teologia ikony, Poznań 1993, s. 61 n (cyt. za: W. Kurpik, Rozmyślając o genezie wizerunków Zbawiciela, dz. cyt., s. 133).

16 A. A. Napiórkowski, Z historii teologii świętych obrazów, dz. cyt., s. 15.

17 Taki tytuł nadano w Rosji wizerunkowi Bogurodzicy-Orantki, a określenie to oznaczało „cud” i „znak” (por. T. Špidlik, M. I. Rupnik, Mowa obrazów, tłum. J. Dembska, Warszawa 2001, s. 99).

18 A. A. Napiórkowski, Z historii teologii świętych obrazów, dz. cyt., s. 13. 
znajduje się Chrystus-Emmanuel ${ }^{19}$. Określenie Emmanuel w języku hebrajskim oznacza „Bóg jest z nami” ${ }^{20}$, a temat ten ma swoją podstawę w tekstach Pisma Świętego. Bezpośrednio odnosi się do niego przepowiednia Izajasza ze Starego Testamentu: „Dlatego sam Pan da wam znak: Oto Panna pocznie i porodzi Syna, i nazwie Go imieniem Emmanuel" (Iz 7, 14). Z Nowego Testamentu zaś pochodzą słowa anioła zwiastującego Maryi: „Duch Święty zstąpi na Ciebie i moc Najwyższego osłoni Cię. Dlatego też Święte, które się narodzi, będzie nazwane Synem Bożym" (Łk 1,35). Obydwa teksty odnoszą się do aktu wcielenia, które dokonało się w łonie ziemskiej niewiasty za sprawą Ducha Świętego. Stąd też typ ikonograficzny „Znak" może też często nosić nazwę „Wcielenie”21, a tajemnica ta została podkreślona przez połączenie dwóch ciał Matki i Syna.

Ikona Bogurodzicy-Orantki jest podobna pod względem kompozycyjnym do przedstawienia kijowskiej „Świętej Sofii”. Zarówno Sofię jak i Theothokos można thumaczyć jako zjednoczenie między Stwórcą a stworzeniem. Bo przecież Słowo Boże przyjęło postać ludzką właśnie wewnątrz Bogurodzicy ${ }^{22}$. Odzwierciedla to również kanon w sztukach plastycznych. Na ikonie ukazany jest okrągły medalion symbolizujący łono Bogurodzicy, w którym począł się Bóg-Człowiek. Chociaż Chrystus jeszcze się nie narodził, to mamy tu wyobrażenie przedwiecznego Logosu ukazanego w Jego preegzystencji ${ }^{23}$. Ikona ta ma więc podstawę chrystologiczną bo Maryja tak naprawdę wskazuje na Chrystusa ${ }^{24}$, a równocześnie wznosi modły do Boga. Natomiast trzeba pamiętać, iż każda modlitwa jest u podstawy swej chrystologiczna, gdyż dociera do Ojca tylko za pośrednictwem Jego Syna ${ }^{25}$. Sam Chrystus modli się w Bogurodzicy, a także i w każdym człowieku, świadczy o tym Jego poza oranta ${ }^{26}$.

Emmanuel wyobrażany na tle okrągłej tarczy (łac. clipeus) lub też wewnątrz okrągłego ciemnego medalionu w sposób obrazowy wskazuje na tajemnicę wcielenia Słowa Bożego. Często występował On sam i nikt mu nie towarzyszył, ale z czasem Jego wizerunek został połączony z przedstawieniem Theothokos, co było charakterystyczne dla sztuki powstającej na terenach chrześcijaństwa wschodnie$\mathrm{go}^{27}$. Przykładem tego typu ikony jest „Orantka” pochodząca z Jarosławia, w której Theotokos unosi do góry ręce w geście modlitewnym. Taką postawę przyjmuje też

19 I. Jazykowa, Świat ikony, dz. cyt., s. 112; E. Smykowska, Ikona. Mały słownik, Warszawa 2008 , s. 93.

20 K. Onasch, A. Schnieper, Ikony, dz. cyt., s. 134.

21 E. Smykowska, Ikona, dz. cyt., s. 93.

22 Por. T. Špidlik, M. I. Rupnik, Mowa obrazów, dz. cyt., s. 99.

${ }^{23}$ I. Jazykowa, Świat ikony, dz. cyt., s. 112; K. Onasch, A. Schnieper, Ikony, dz. cyt., s. 134.

24 E. Smykowska, Ikona, dz. cyt., s. 93.

25 T. Špidlik, M. I. Rupnik, Mowa obrazów, dz. cyt., s. 99; J 16, 23: Et in illo die me non rogabitis quidquam. Amen, amen dico vobis: si quid petieritis Patrem in nomine meo, dabit vobis.

26 T. Śpidlik, M. I. Rupnik, Mowa obrazów, dz. cyt., s. 101.

27 Por. K. Onasch, A. Schnieper, Ikony, dz. cyt., s. 134. 
Emmanuel, który skierowany wprost do widza równocześnie udziela błogosławieństwa $^{28}$. Jego głowę otacza krzyżowy nimb ${ }^{29}$ mówiący o tym, że mamy do czynienia ze Zbawicielem, który poniesie ofiarę podczas śmierci na krzyżu. Na ikonach Chrystus może też dodatkowo w jednej ręce trzymać zwój symbolizujący Jego naukę ${ }^{30}$. Chrystus chociaż jeszcze się nie narodził w ciele, został ukazany w łonie Matki jako Słowo wiecznie istniejące. To nawiązuje do anamnezy liturgicznej, gdzie wspomnienie sprawia, że Zbawiciel rzeczywiście staje się obecny w Eucharystii. Również na ikonie wyrażono symbolicznie fakt, że to, co najpierw zaistniało w myśli, dało następnie początek realnej rzeczywistości. Znaczy to, że Bogurodzica najpierw poczęła Chrystusa w swoim sercu a dopiero później w ciele $^{31}$. Słowo określa i wypełnia wnętrze Matki a tym samym i każdego wiernego. Tak jak każda ikona, tak i ta wprowadza do świata duchowego. Jest ona teofanią, co znaczy, że zaświadcza o obecności Tego, kto jest przedstawiany, zachęca do modlitwy i adoracji ${ }^{32}$.

Ten symboliczny obraz wiecznie egzystującego Syna Bożego posiada charakterystyczne cechy. Co prawda Chrystus ma proporcje dziecka lub też młodzieńca, niemniej rysy jego twarzy wskazują na mężczyznę $e^{33}$. Posiada On wysokie duże czoło, podkreślające mądrość, duże zamyślone oczy, bardzo dojrzały wyraz twarzy, typowy dla osoby dorosłej, która pogrążyła się w refleksji. W ten sposób nawiązywano do znanego w sztuce antycznej wzoru zwanego paidariogerion, który przedstawiał dziecko przypominające z wyglądu starca ${ }^{34}$.

Ikony ukazujące Emmanuela mają na celu ukazanie Chrystusa jako zapowiadanego Syna Bożego. Wyraźne jest tu nawiązanie nie tylko do proroctwa Izajasza $(7,14)$, ale także do tekstów ewangelicznych. Z Ewangelii św. Mateusza pochodzą słowa skierowane do Józefa: „Porodzi Syna, któremu nadasz imię Jezus, On bowiem zbawi swój lud od jego grzechów. A stało się to wszystko, aby się wypełniło Słowo Pańskie powiedziane przez Proroka: «Oto Dziewica pocznie i porodzi Syna, któremu nadadzą imię Emmanuel, co znaczy ‘Bóg z nami'»” (Mt 1, 21-23).

Trzeba tutaj podkreślić, że Emmanuel często występował sam, co miało wskazywać na na fakt, że istniał On jeszcze przed dokonaniem się aktu Wcielenia. Było to zgodnie z symbolem nicejsko-konstantynopolitańskim, w którym ojcowie potwierdzili wiarę w „Syna Bożego jednorodzonego, zrodzonego z Ojca przed wszystkimi wiekami”’35. Samodzielnego znaczenia wizerunek Emmanuela nabierał

28 Por. I. Jazykowa, Świat ikony, dz. cyt., s. 112.

29 E. Smykowska, Ikona, dz. cyt., s. 23.

30 I. Jazykowa, Świat ikony, dz. cyt., s. 112, 83.

31 T. Špidlik, M. I. Rupnik, Mowa obrazów, dz. cyt., s. 101.

32 Por. P. Evdokimov, Prawostawie, Warszawa 1996, s. 285; P. Nowakow ski, Liturgiczna funkcja ikony w obrzadku bizantyjskim, „Liturgia Sacra” 10 (2004), s. 313.

${ }_{33}$ K. Onasch, A. Schnieper, Ikony, dz. cyt., s. 133.

34 Tamże, s. 134.

35 Sobór Konstantynopolitański I (381), Wyznanie wiary 150 Ojców, w: Dokumenty soborów powszechnych, t. I, dz. cyt., s. 68: [...] filium dei unigenitum, ex patre natum ante omnia saecula. 
w tzw. ,anielskich Deesis”, gdzie ukazywany był przed stojącymi przed nim aniołami. Tego typu wyobrażenia spotykane było we wczesnej sztuce ruskiej w niskich przegrodach ołtarzowych zanim jeszcze wykształcił się wysoki ikonostas ${ }^{36}$. Oczywiście umieszczenie Jego postaci przed Bogurodzicą i na tle okrągłego medalionu można interpretować także jako zapowiedź Wcielenia. Być może dlatego początkowo nie starano się przedstawiać Go pod postacią dziecka, a nawet początkowo w sztuce bizantyńskiej popularne były wizerunki dorosłego człowieka, w których wzorowano się na ikonografii Odwiecznego Dniami ${ }^{37}$.

\section{CHRYSTUS BARANEK BOŻY (CZĄSTKA PROSFORY)}

Temat ikonograficzny Baranka Bożego w symboliczny sposób ukazuje najważniejszą część sprawowanej liturgii, jaka dokonuje się za przegrodą ołtarzową (ikonostasem), a więc ilustruje to, co pozostaje zasłonięte przed wzrokiem wi$\mathrm{dza}^{38}$. A trzeba pamiętać, że wszystko, co znajdowało się za ikonostasem, symbolizowało rzeczywistość niebiańską i otoczone było tajemnicą. Należy dodać, że wszelkiego rodzaju obrazy sakralne umieszczone w świątyni mogą być rozumiane właśnie w kontekście liturgii ${ }^{39}$. Pełnią one w niej tak samo ważną funkcję, jak celebrujący liturgię kapłani ${ }^{40}$. Ikony są fenomenem artystycznym, muszą istnieć w określonym środowisku, gdyż w innej przestrzeni umierają i przestają być dobrze rozumiane ${ }^{41}$.

Ikonograficzna tematyka, jaka występuje w cerkwiach nawiązuje ściśle do liturgii, a w tym konkretnym wypadku do czynności jakie kapłan dokonuje w trakcie proskomidii, czyli liturgii przygotowania darów: chleba i wina. Ryt ten po grecku nosi nazwę ,przynoszenie”, jest wstępną częścią liturgii i polega na tym, że kapłan przy pomocy malutkiej włóczni dokładnie wydziela z chleba eucharystycznego (prosfory, z gr. ofiara) poszczególne części. Środkowa Cząstka utożsamiana ze Zbawicielem, czyli Barankiem Bożym jest najważniejsza i dlatego po złożeniu jej na patenie (gr. diskos) otaczana jest innymi cząstkami oznaczającymi

36 I. Jazykowa, Świat ikony, dz. cyt., s. 84.

37 K. Onasch, A. Schnieper, Ikony, dz. cyt., s. 134.

38 Tamże, s. 137.

39 Liturgia - w języku greckim oznacza „,wspólny czyn” lub też „działanie na rzecz ludu”. Teraz terminem tym określa się wszelkie zrytualizowane, sakralne czynności, które wchodzą w skład publicznego kultu. Kult ten składający się z różnych modlitw i ofiar służy do oddawania czci Bogu (por. M. Kunzler, Liturgia Kościoła, Poznań 1999). W chrześcijaństwie liturgia związana jest z Ofiarą Eucharystyczną, która wymaga określonej oprawy artystycznej (por. Z. Fudakowska, Liturgia a sztuka, Poznań 1934). Szczególnie widać to w Kościele wschodnim, gdzie ważną rolę podczas sprawowania liturgii posiada ikona. Ten sakralny obraz jest ze swej natury liturgiczny i tylko tak można go odczytywać, by zrozumieć jego głęboki sens (por. I. Jazykowa, Świat ikony, dz. cyt., s. 41).

40 Por. J. Czerski, Boska liturgia św. Jana Chryzostoma, Opole 1998, s. 44n.

${ }^{41}$ P. Florenski, Ikonostas i inne szkice, tłum. Z. Podgórzec, Warszawa 1984, s. 29. 
poszczególne osoby mające swój udział w procesie zbawczym. Występują więc tu cząstki symbolizujące Theothokos, Jana Prodromosa oraz reprezentantów Starego i Nowego Testamentu, czyli proroków zapowiadających przyjście Zbawiciela, następnie apostołów i świętych oraz wszystkich członków Kościoła, tworzących Ciało Chrystusa ${ }^{42}$. Wszyscy oni tworzą hierarchię niebiańską i ziemską. Podobne zestawienie tych osób, jakie przejawia się w układzie świętych cząstek, widoczne jest na ścianie ikonostasu, zwłaszcza w rzędzie Deesis (gr. błaganie, wstawiennictwo), gdzie orędownicy wstawiają się do Chrystusa za ludzkością ${ }^{43}$.

Już od IV wieku znano czynność wydzielania środkowej części z chleba eucharystycznego, którą utożsamiano z Barankiem złożonym w ofierze. Ten ryt w symboliczny sposób został zobrazowany na przedstawieniu zwanym melismos (od gr. melizo oznaczającym łamanie lub rozczłonkowanie sakralnego chleba). Sama nazwa wyraźnie nawiązuje do obrzędu dzielenia jednej prosfory na mniejsze cząst$\mathrm{ki}^{44}$. Stąd i wyobrażenie to nosi też nazwę Amnos (gr. baranek), którym określano Odkupiciela pod postacią Dzieciątka ${ }^{45}$. Przeważnie jest On ukazywany w otoczeniu adorujących Go aniołów, którzy trzymają rypidiony (gr. rhypidion), czyli okrągłe wachlarze używane $\mathrm{w}$ trakcie liturgii ${ }^{46}$.

Ponieważ to przedstawienie ściśle związane było z liturgią, również jego umiejscowienie miało istotną rolę. Ludzie zgromadzeni w świątyni nie mogli go bezpośrednio widzieć, gdyż znajdowało się ono zasłonięte za ścianą ikonostasu. Nie istniała więc konieczność tworzenia ikon z tym tajemniczym tematem, częściej zaś mamy do czynienia z mozaikami i malowidłami na ścianach ${ }^{47}$.

Tak jak wszystkie obrazy sakralne, tak również i ten nie ma na celu rzeczywistego portretowania Zbawiciela, lecz jest ikoną Jego obecności. Można więc stwierdzić, że freski i ikony znajdujące się wewnątrz świątyni przedstawiały prawdziwą tajemnicę, które uobecnia się właśnie w Kościele. Ukazywały one sceny zbawcze nierozerwalnie związane z Chrystusem, co sprawiało, że rzeczywiście stawał się On obecny w liturgii, a przede wszystkim w Eucharystii. Pomimo, że ryty liturgiczne znane były już dość wcześnie, to jednak temat Dzieciątka

${ }^{42}$ K. Onasch, A. Schnieper, Ikony, dz. cyt., s. 137. Definicję proskomidii zob. I. Jazykowa, Świat ikony, dz. cyt., s. 226 (por. A. Mień, Sakrament, słowo, obrzęd. Prawosławna Stużba Boża, Łuków 1992, s. 48n).

43 W kompozycji Deesis centralne miejsce zajmuje postać Chrystusa („Zbawiciel w chwale” lub Pantokrator), otaczają Go z jednej strony Bogurodzica, zaś z drugiej Jan Prodromos, za nimi zaś apostołowie i Ojcowie Kościoła (por. I. Jazykowa, Świat ikony, dz. cyt., s. 209).

44 K. Onasch, A. Schnieper, Ikony, dz. cyt., s. 137 (por. H. J. Schulz, The Byzantine liturgy, New York 1986, s. 105-111; P. Now akow ski, Liturgiczna funkcja ikony w obrzadku bizantyjskim, dz. cyt., s. 321).

45 K. Onasch, A. Schnieper, Ikony, dz. cyt., s. 137.

46 Ripidion (gr. wachlarz) - pozłacany krąg umieszczony na długiej rączce. To utensilium liturgiczne początkowo służyło do odpędzenia owadów od darów eucharystycznych. Ważną funkcję spełnia podczas święceń diakonów (por. I. Jazykowa, Świat ikony, dz. cyt., s. 227).

47 K. Onasch, A. Schnieper, Ikony, dz. cyt., s. 137. 
ukazywanego jako Baranka Bożego pojawił się dość późno. Najstarsze freski znane są z końca XII wieku ${ }^{48}$.

\section{III. „CZUWAJĄCE OKO CHRYSTUSA”}

Kompozycja ta nosząca też nazwę „Nieśpiące Oko”, popularna w sztuce bizantyjskiej i południowosłowiańskiej w XIV-XVI wieku, ukazuje w centrum Chrystusa spoczywającego na łożu. $\mathrm{Z}$ tego też powodu odnosi się do niego greckie określenie Anapeson, co znaczy spoczywający ${ }^{49}$, pogrążony, lub też znajdujący się w stanie śmierci ${ }^{50}$. Jednak Syn Boży tylko pozornie spoczywa, a tak naprawdę nie śpi. Otwarte oczy wskazują na fakt, że posiada całkowitą wiedzę i nieustannie się troszczy o stworzony przez siebie świat ${ }^{51}$.

$\mathrm{Na}$ Rusi do tego typu przedstawień odnosiły się też określenia Niedriemannoje Oko a także „Obrońca Izraela” oraz „Który Nie Śpi”52. Wszystkie te nazwy nawiązywały do wersetu z psalmu 121 (120), 3-5: „On nie pozwoli zachwiać się twej nodze, ani się nie zdrzemnie Ten, który cię strzeże. Oto nie zdrzemnie się, ani nie zaśnie Ten, który czuwa nad Izraelem. Pan cię strzeże, Pan twoim cieniem przy twym boku prawym"53. Zazwyczaj Chrystus ułożony jest na łożu, co sprawia, że wydaje się odpoczywać zatopiony we śnie ${ }^{54}$. Zbawiciel jednak nie zamyka oczu, co wskazuje, że w przyszłości pokona śmierć. Co prawda leży, ale tak naprawdę Jego pozycja jest dość niespokojna, jakby zaraz miał powstać z grobu ${ }^{55}$.

Przedstawiony jest On tu jako młodzieniec, a niekiedy nawet jako dziecko w charakterze Emmanuela ${ }^{56}$, którego otaczają z obu stron: Theothokos oraz aniołowie z różnymi atrybutami. Takiego rodzaju przedstawienie rozwijało się w późnej sztuce bizantyjskiej przede wszystkim w formie obrazu na ścianie wewnątrz świątyni ${ }^{57}$ a dopiero potem $\mathrm{w}$ ikonografii, szczególnie od XIV w. ${ }^{58}$ Ten schemat ikonograficzny rozpowszechniał się w zwłaszcza w XVI-XVII wieku, kiedy popularnością cieszyły się sceny symboliczne oraz te odnoszące się do dogmatów

48 Tamże.

49 A. Sulikowska, „Życie śpi, a piekło drży z trwogi”, „,Czuwające Oko Chrystusa” jako wyobrażenie męki i chwaty Zbawiciela w ikonografii staroobrzędowców, w: Chrystus wybawiajacy, dz. cyt., s. $185,193$.

50 K. Onasch, A. Schnieper, Ikony, dz. cyt., s. 136.

51 Por. A. Sulikowska, „Życie śpi, a piekło drży z trwogi”, dz. cyt., s. 189.

52 Por. K. Onasch, A. Schnieper, Ikony, dz. cyt., s. 136.

53 Por. I. Jazykowa, Świat ikony, dz. cyt., s. 84; A. Sulikowska, „Życie śpi, a piekło drży z trwogi”, dz. cyt., s. 189, 202; K. Onasch, A. Schnieper, Ikony, dz. cyt., s. 136.

54 Por. K. Onasch, A. Schnieper, Ikony, dz. cyt dz. cyt., s. 136.

55 Por. A. Sulikowska, „Życie śpi, a piekło drży z trwogi”, dz. cyt., s. 199-200.

56 K. Onasch, A. Schnieper, Ikony, dz. cyt., s. 136.

57 Por. I. Bentchev, Engelikonen. Machtvolle Bilder himmelischer Boten, Freiburg-Basel-Wien 1999, s. 180, (podaję za: A. Sulikowska, ,Życie śpi, a piekło drży z trwogi”, dz. cyt., s. 185).

58 I. Jazykowa, Świat ikony, dz. cyt., s. 84. 
i ilustrujące ryty liturgiczne ${ }^{59}$. Widać tu wyraźnie, że sakralny obraz związany jest z liturgią i można go zrozumieć tylko w obrębie akcji liturgicznej, w której on także uczestniczy.

Schemat ikonograficzny został rozbudowany w ten sposób, aby streszczał całą ekonomię zbawczą związaną ze wcieleniem się Drugiej Osoby Boskiej. Podkreślono tu fakt, że zbawienie świata uzależnione było od kenozy ${ }^{60}$ Syna Bożego, którzy uniżył się i przyjął ludzkie ciało ${ }^{61}$. Sam kanon opisywanej tu kompozycji został opracowany na podstawie nie tylko Pisma Świętego, ale także chrześcijańskich źródeł pozabiblijnych ${ }^{62}$. Wyraźnie nawiązano tu do przyrodniczego dzieła Physiologos, w którym opisano zwyczaje lwa. Według autora tego tekstu lew, nawet gdy śpi to zachowuje nieustanną gotowość do aktywności o czym świadczą jego otwarte oczy. Chrześcijanie zauważyli tutaj analogię do faktu, że chociaż ciało Zbawcy pogrążyło się w głębokim śnie, gdy wisiało na krzyżu, to jednak Jego boska natura nadal wykazywała czujność, nigdy nie zgasła, gdyż wiecznie przebywała ze swym Ojcem ${ }^{63}$. Istniało też powszechne przekonanie, według którego mały lew, co prawda rodzi się jakby martwy, ale ożywia się i odzyskuje ducha na trzeci dzieńn ${ }^{64}$. Wówczas ojciec lew budzi swym ożywczym oddechem lwiątko, które zostaje przeznaczone do panowania nad wszystkimi zwierzętami. Występuje tu analogia z faktem, że Bóg Ojciec po trzech dobach budzi swego zmarłego Syna, by odnowił całą ludzkośćc5.

Istniało wiele wariantów tego typu wyobrażeń. Na obszarze Rusi schemat ten znany był od XV wieku ${ }^{66}$. Przedstawiał się on w następujący sposób: w centrum ukazany jest spoczywający Chrystus, asystują Mu, po jednej stronie Bogurodzica, zaś po drugiej anioł ${ }^{67}$. Jeśli był to archanioł Gabriel, to w pewnym sensie można mówić o powtórzeniu sceny Zwiastowania. Odczytuje się to też jako zapowiedź Wcielenia, które zapoczątkowało ekonomię zbawczą ${ }^{68}$. Na innych wyobrażeniach naprzeciw Theothokos po drugiej stronie Zbawiciela stoi Archanioł Michał,

59 A. Sulikowska, „Życie śpi, a piekło drży z trwogi”, dz. cyt., s. 193, 197.

60 Gr. kenosis, oznacza ogołocenie, wyniszczenie (por. P. Janow ski, Kenoza w teologii katolickiej i teologii protestanckiej, w: Encyklopedia Katolicka, t. VIII, Lublin 2000, kol. 1346-1348).

${ }^{61}$ Flp 2, 6-8: Qui cum in forma Dei esset, non rapinam arbitratus est esse se cequalem Deo: sed semetipsum exinanivit, formam servi accipiens, in similitudinem hominum factus, et habitu inventus ut homo. Humiliavit semetipsum factus obediens usque ad mortem, mortem autem crucis.

62 K. Onasch, A. Schnieper, Ikony, dz. cyt., s. 136.

63 Tamże (por. Le Physilogus. Poeme sur la nature des animaux en grec vulgaire et en vers politiques, Paris 1873, s. 96n; A. Sulikowska, „Życie śpi, a piekto drży z trwogi”, dz. cyt., s. 187-188).

${ }^{64}$ K. Onasch, A. Schnieper, Ikony, dz. cyt., s. 136.

65 A. Sulikowska, ,Życie śpi, a piekło drży z trwogi”, dz. cyt., s. 186.

66 Por. N. P. Kondakow, Russkaja ikona, Praga 1931, s. 284 (podaję za: A. Sulikowska, „Życie śpi, a piekło drży z trwogi”, dz. cyt. s. 195).

67 A. Sulikowska, „Życie śpi, a piekło drży z trwogi”, dz. cyt., s. 196.

68 I. Jazykowa, Świat ikony, dz. cyt., s. 84. 
dzierżący w ręku krzyż ${ }^{69}$. Zdarzało się, że nad Chrystusem unosił się anioł z wachlarzem, lub też zlatywali się dwaj aniołowie trzymający w dłoniach symbole męki Pańskiej, czyli włócznię, trzcinę i krzyż ${ }^{70}$. Na niektórych ikonach ruskich aniołowie znajdujący się górnej partii kompozycji trzymali w dłoniach rypidiony (wachlarze) $)^{71}$, tak samo jak to występowało w schemacie ikonograficznym ukazującym Dzieciątko jako Amnos, czyli Baranka Bożego ${ }^{72}$.

Trzeba również podkreślić, iż na symbolicznych wyobrażeniach Chrystus zachowuje ludzką postać, gdyż dobrowolnie przyjął naturę człowieka (Flp 2, 7). Co prawda na ikonach wyrażano Jego Bóstwo, jednak nigdy człowieczeństwo nie zostało przesłonięte. Zawsze obok aspektu chrystologicznego widoczny jest też aspekt antropologiczny ${ }^{73}$.

Oczywiście w całej scenie widoczna jest też obecność całego Trójosobowego Boga. Często w górnej części ikony wewnątrz półkolistej hemisfery symbolizującej rzeczywistość niebiańską włania się wyobrażenie Odwiecznego Dniami, którego wygląd zgodny jest z opisem zawartym w proroctwie Daniela (por. Dn 7, 9. 13-14) $)^{74}$. Wizerunek ten podkreśla wszechpotęgę całego Boga kierującego ekonomią zbawienia.

Wyobrażenie „Czuwające oko” ściśle związana jest z rytem liturgicznym, dokonywanym w pierwszym etapie przygotowania do Eucharystii. Kompozycja została tak przygotowana, aby ilustrowała czynność zwaną proskynesis (gr. przynoszenie) polegającą na przygotowaniu chleba i wina. Wówczas celebrans wydzielał z jednej prosfory kilka mniejszych części, z których najważniejsza jest środkowa oznaczająca Baranka Bożego składanego w ofierze. Inne cząstki ułożone wokół Niego oznaczają Theotokos, Jana Prodromosa, hierarchie niebiańską oraz wszystkich wiernych ${ }^{75}$. Ponieważ ryt ten dokonywany był w miejscu zwanym prothesis, dlatego też przedstawienie nawiązujące do tej sakralnej czynności często umieszczano w tej kaplicy.

Scena ukazująca Nieśpiącego Chrystusa pod względem kompozycyjnym wykazuje też podobieństwo do schematu zwanego melismos ukazującego Chrystusa jako Dzieciątko i utożsamianego z Czastką prosfory ${ }^{76}$.

69 K. Onasch, A. Schnieper, Ikony, dz. cyt., s. 136.

70 A. Sulikowska, „Życie śpi, a piekło drży z trwogi”, dz. cyt., s. 196.

71 Por. I. Jazykowa, Świat ikony, dz. cyt., s. 227.

72 A. Sulikowska, ,Życie śpi, a piekło drży z trwogi”, dz. cyt., s. 194.

73 Por. A. A. Napiórkowski, Z historii teologii świętych obrazów, dz. cyt., s. 13.

74 Dn 7, 9: Aspiciebam donec throni positi sunt, et antiquus dierum sedit. Vestimentum ejus candidum quasi nix, et capilli capitis ejus quasi lana munda: thronus ejus flammo ignis: rotce ejus ignis accensus. Dn 7, 13-14: Aspiciebam ergo in visione noctis, et ecce cum nubibus caeli quasi filius hominis veniebat, et usque ad antiquum dierum pervenit: et in conspectu ejus obtulerunt eum. Et dedit ei potestatem, et honorem, et regnum: et omnes populi, tribus, et linguce ipsi servient: potestas ejus, potestas ceterna, quce non auferetur: et regnum ejus, quod non corrumpetur.

75 I. Jazykowa, Swiat ikony, dz. cyt., s. 226.

76 K. Onasch, A. Schnieper, Ikony, dz. cyt. s. 137. 


\section{WIZERUNEK SYNA BOŻEGO W WYOBRAŻENIACH TRÓJCY ŚWIĘTEJ}

\section{Trójca Święta typu Starotestamentowego}

Kanon ikonograficzny tego tematu ukształtował się na podstawie tekstu z Księgi Rodzaju 18, 1-8, gdzie opisano scenę ukazania się Abrahamowi i Sarze trzech Bożych posłańców. Za klasyczny przykład tego typu ikony uważa się dzieło ruskiego mnicha -Andrzeja Rublowa ${ }^{77}$, który pomijając aspekt historyczny od razu przeszedł w wymiar symboliczny ${ }^{78}$ i ukazał wyłącznie trzech aniołów-posłańców bez postaci Abrahama i Sary.

Istnieją rozbieżności co do faktu, który z aniołów miał by być utożsamiany z Drugą Osobą Trójcy Świętej. Niektórzy twierdzą, że to anioł po lewej stronie symbolizuje Syna Bożego. Wówczas w środku znajdowałby się Bóg Ojciec, a po Jego prawej stronie Syn. Podczas gdy Ojciec błogosławi kielich i poleca misję Synowi, to Syn posłusznie godzi się na to polecenie ${ }^{79}$. Pod tym względem można tutaj przywołać tekst św. Mateusza 26, 64: „Ujrzycie Syna Człowieczego, siedzącego po prawicy Wszechmogącego".

Odwoływano się też do istnienia ikony należącej do św. Stefana z Permu, na której po lewej stronie znajduje się Syn. Podkreśla to napis, „Py” oznaczający w języku zyriańskim Syna ${ }^{80}$. Na fakt, że mamy do czynienia z Chrystusem wskazywać ma specyficzna barwa Jego szat. Zewnętrzny himation posiada cielistą barwę, co sygnalizuje, że Chrystus przyjął postać cielesną. Ta ludzka natura zasłoniła przed ludzkim wzrokiem Jego boską naturę. Niemniej jednak pod spodem widoczny jest fragment chitonu, barwy błękitnej oznaczającej właśnie Bóstwo ${ }^{81}$. Za tym aniołem znajduje się pałac, który można interpretować nie tylko dosłownie jako budynek, ale jako symbol Kościoła, czyli ciało Chrystusa (por. Ef 1, 23) ${ }^{82}$.

Według większości interpretacji to środkowy anioł jest utożsamiany z Chrystusem. Kielich eucharystyczny znajdujący się na stole-ołtarzu symbolizuje ofiarę Syna Bożego, jest błogosławiony przez Ojca, który poleca w ten sposób Jednorodzonemu do wykonania zadanie. Syn znajdujący się w środku przyjmuje postawę pokorną wobec Ojca, co przejawia się w Jego pozycji ciała i pochyleniu głowy. Wstawia się u Ojca za rodzajem ludzkim, a Jego dłoń jest opuszczona w kierunku

$77 \mathrm{Na}$ ten temat, zob. G. Bunge, Inny Paraklet. Ikona Trójcy Świętej mnicha-malarza Andrzeja Rublowa, tłum. K. Małuys, Tyniec-Kraków 2001; B. Standaert, Ikona Trójcy Andrzeja Rublowa, Bydgoszcz-Kraków 1997 (2002).

78 I. Jazykowa, Świat ikony, dz. cyt., s. 92.

79 Tamże, s. 95.

80 Por. P. Evdokimov, Sztuka ikony. Teologia piękna; tłum. M. Żurowska, Warszawa 1999, s. 208 .

81 I. Jazykowa, Świat ikony, dz. cyt., s. 95.

82 Ef 1, 22-23: Et ipsum dedit caput supra omnem ecclesiam, qua est corpus ipsius. 
kielicha ${ }^{83}$. W tym wypadku za Synem znajduje się dąb Mambre, z którego drzewa według legendarnych przekazów zrobiony był też krzyż męki Chrystusowej. Umieszczenie drzewa za Chrystusem wskazuje również na fakt, że to On jest owocem tego drzewa i gwarantuje żywot wieczny każdej osobie, która Go spożyje. Pod drzewem życia widoczny jest więc prawdziwy owoc poznania, którego poszukiwał pierwszy człowiek ${ }^{84}$.

Srodkowy aniołnajbardziej skupia wzrok obserwatora,m.in. dzięki intensywnym barwom swojego ubioru. Dobór kolorystyczny szat ma także swoje uzasadnienie teologiczne, nawiązuje do dogmatu określonego na Soborze Chalcedońskim (451), według którego Syn Boży jest doskonały zarówno w bóstwie jak i w człowieczeństwie. To równocześnie prawdziwy Bóg, jak i prawdziwy człowiek ${ }^{85}$. Spodni chiton w kolorze intensywnie wiśniowym przykryty jest zewnętrznym himationem o barwie lapis-lazuli. Zestawienie tych kontrastujących barw wskazywać ma na połączenie w Chrystusie dwóch natur. Błękit oznacza boskość, purpura człowieczeństwo, a także królewski majestat ${ }^{86}$. Istnieje też inne uzasadnienie teologiczne, według którego to czerwień określa ognistą boskość, a kolor niebieski człowieczeństwo ${ }^{87}$. Zaś złota przepaska na głowie symbolizuje boską chwałę, na którą zasłużył Syn po wykonaniu zbawczej misji ${ }^{88}$.

O dwóch naturach mogą przypominać też dwa wysunięte palce dłoni, którą Chrystus przyjmuje kielich. Świadczyłoby to również, że dobrowolnie godzi się On, by stać się ofiarą złożoną na ołtarzu ${ }^{89}$. Środkowa postać ukazana jest frontalnie, co świadczy, że daje się całkowicie poznać, w przeciwieństwie do dwóch pozostałych aniołów ukazanych w lekkim profilu. Taki zabieg artystyczny podkreśla fakt, że to Druga Osoba w akcie Wcielenia przyjęła ludzką postać stając się w pełni osiągalna dla ludzi, a nie dotyczyło to dwóch pozostałych Osób Boskich. Co prawda ciało Chrystusa było widzialne, ale Boskość nadal pozostawała poza zasięgiem zmysłów. Niemniej jednak już św. Paweł w Liście do Kolosan określił Chrystusa: „On jest obrazem Boga niewidzialnego” (Kol 1, 15). Również sam Chrystus powiedział o sobie: „Kto mnie zobaczył, zobaczył także Ojca” (J 14, 9). Z tej to przyczyny Ojca w pełni można poznać patrząc właśnie na Syna, który stanowi rzeczywistą ikonę Ojca ${ }^{90}$. Dlatego też dwaj aniołowie, ten znajdujący się po

83 Por. L. Balter, Pneumatologia ikony, w: Chrystus wybawiajacy, dz. cyt., s. 84.

84 T. Špidlik, M. I. Rupnik, Mowa obrazów, dz. cyt., s. 30.

85 Por. Sobór Chalcedoński (451), Definicja wiary 11, w: Dokumenty soborów powszechnych, t. I, dz. cyt., s. 222: [...] eundem perfectum in deitate, eundem perfectum in humanitate [...] Deum verte et hominem verte $[. .$.$] .$

86 Na temat szat Chrystusa, zob. E. Smykowska, Ikona, dz. cyt., s. 43; A. Adamska, Teologia piękna na przykładzie ikon Andreja Rublowa, Kraków 2003, s. 127.

87 T. Špidlik, M. I. Rupnik, Mowa obrazów, dz. cyt., s. 30.

88 L. Balter, Pneumatologia ikony, dz. cyt., s. 84.

89 Por. A. Adamska, Teologia piękna na przykładzie ikon Andreja Rublowa, dz. cyt., s. 129.

90 I. Jazykowa, Świat ikony, dz. cyt., s. 95. 
lewej, jak i ten w środku mogli być utożsamiani zarówno z Ojcem jak i z Synem. Teologicznie tłumaczy się, to w ten sposób, iż patrzenie na Pierwszą Osobę Trójcy jest tak naprawdę możliwe poprzez Drugą Osobę. Wobec tego oblicze Syna Bożego objawia Osobę Boga Ojca ${ }^{11}$. Jednorodzony Syn zwraca się ku Ojcu, gdyż jest zrodzony przez Niego i Syn równocześnie uznaje swego Ojca ${ }^{92}$.

Trzeba podkreślić, że Trójca Rublowa jest niehipostatyczna. Tak naprawdę wszystkie z przedstawionych postaci mogły być utożsamiane z każdą z Osób Trójcy Świętej. Dlatego też początkowo artyści nie umieszczali nimbu krzyżowego wokół głowy środkowego anioła oraz inskrypcji IC XC, bo to już stanowiłoby określenie Syna Bożego ${ }^{93}$. Również Sobór Stu Rozdziałów, zabraniał takiej praktyki ${ }^{94}$.

\section{Trójca Święta typu Nowotestamentowego}

W „Trójcy” Starotestamentowej nie chodziło o przedstawienie poszczególnych Hipostaz Trójcy Świętej, lecz o ukazanie Boga objawiającego się w całości. Jednak pod wpływem ikonografii zachodniej w XVI wieku wykształciły się nowe schematy ikonograficzne, które nosiły nazwę „Trójcy” Nowotestamentowej ${ }^{95}$. Tutaj wszystkie Trzy Osoby Boskie są ściśle określone a każda z Nich posiada postać charakterystyczną tylko dla siebie.

Ogólnie w przedstawieniach Trójcy Świętej kontrowersje zawsze wzbudzało przedstawienie Pierwszej i Trzeciej Osoby Trójcy, które są niewyobrażalne. Możliwość ukazywania Boga w ciele odnosiła się tylko do Drugiej Osoby, która wcielając się przyjęła ludzką postać. To potwierdził również Moskiewski Sobór Stu Rozdziałów ${ }^{96}$. Mimo zakazów kościelnych dość często wykonywano przedstawienia „Trójcy Nowotestamentowej”, w których wyraźnie rozróżniano poszczególne Osoby Trójcy. W wyobrażeniach typu Ojcostwo, Bóg Ojciec ukazywany jest pod postacią starca, Syn Boży jako dojrzały mężczyzna, a Duch Święty jako unosząca się gołębica ${ }^{97}$.

Istnieje kilka typów Trójcy Nowotestamentowej. W schemacie „Wspólny Tron” na obszernej ławie, czy też tronie Syn Boży zasiada po prawej stronie Boga Ojca",

91 Por. Ch. Schönborn, Ikona Chrystusa; tłum. W. Szymona, Poznań 2001, s. 39.

92 T. Špidlik, M. I. Rupnik, Mowa obrazów, dz. cyt., s. 31.

93 I. Jazykowa, Świat ikony, dz. cyt., s. 94.

94 Por. E. Smykowska, Ikona, dz. cyt., s. 80. Sobór ten odbyty w Moskwie w 1551 roku uznał, że „Trójca Święta” Andrzeja Rublowa jest dziełem wzorcowym i godnym naśladowania (por. E. Smykowska, Ikona, dz. cyt., s. 74). Synod „Stogław” ustalił: „Trzeba, by artyści malowali ikony według tradycji, by wzorowali się na przykładach malarzy greckich, na Andrzeju Rublowie innych" (cyt. za: I. György, F. Nemenyi, Rublow. Malarz fresków i ikon, thum. H. Keszycka, Warszawa 1979, s. 7).

95 I. Jazykowa, Świat ikony, dz. cyt., s. 97; E. Smykowska, Ikona, dz. cyt., s. 80.

96 Por. tamże, s. 98.

97 Tamże, s. 97.

98 K. Onasch, A. Schnieper, Ikony, dz. cyt., s. 144-145; K. Sommer, Ikonen. Ein Hanbuch für Sammler und Liebhaber, München 1979, s. 52 (cyt. za: L. Balter, Pneumatologia ikony, dz. cyt., s. 85). 
co nawiązuje do słów: „Pan Jezus został wzięty do nieba i zasiadł po prawicy Boga" (Mk 16, 19). Szaty Chrystusa są błękitno-czerwone, co ma wskazywać na Jego boską i ludzką naturę. Zbawiciel przyjmuje postawę frontalną podobnie jak i Ojciec. Dzierży też w dłoni krzyż wskazujący na Jego ofiarę lub księgę Ewangeliii $^{99}$. Wielokrotnie podkreślano fakt, że Chrystus posiada taką samą władzę jak i Ojciec i panuje wraz z Nim nad całym stworzonym wszechświatem. $Z$ tego też względu często malowano ich jak razem trzymali kulę ziemską umieszczoną pośrodku kompozycji ${ }^{100}$.

Do popularnego schematu ikonograficznego zalicza się temat „Ojcostwo"101, w sztuce wschodniej zwany jako Otieczestwo, a w zachodniej jako Paternitas ${ }^{102}$. W tym wypadku umieszczenie wizerunku Chrystusa w łonie Boga Ojca jest nawiązaniem to ikony typu „Znak” (zwanej też Wcieleniem), gdzie podkreślano macierzyństwo Theotokos. Natomiast tutaj na pierwszy plan wysuwa się „ojcostwo” Boga Ojca. Wszystkie trzy Osoby Trójcy znajdują się na głównej osi kompozycji. Bezpośrednio na tronie zasiada Bóg Ojciec pod postacią Starca (Sabaoth). Trzyma On na kolanach, na poziomie swojego łona umiłowanego Syna przedstawionego w wieku dziecięcym. Chrystus zaś trzyma na piersi medalion z gołębicą Ducha Świętego ${ }^{103}$. Kompozycyjnie przedstawienie to nawiązuje do schematu Spas $w$ Siłach $^{104}$.

Przy opracowaniu tego kanonu ikonograficznego nawiązywano do opisu wizji jaką doznał prorok Daniel (Dn 7, 9. 13-14): „Patrzyłem, aż postawiono trony, a Przedwieczny zajął miejsce. [...] A oto na obłokach nieba przybywa jakby Syn Człowieczy. Podchodzi do Przedwiecznego i wprowadzają Go przed Niego. Powierzono Mu panowanie, chwałę i władzę królewską, a służyły Mu wszystkie narody, ludy i języki”. Podczas gdy Ojciec ukazany jest jako Odwieczny Dniami, to Syn przybiera postać Dzieciątka-Emmanuel, co nawiązuje do tekstu z Księgi Izajasza: „Dlatego Pan sam da wam znak: oto Panna pocznie i porodzi Syna, i nazwie Go Emmanuel" (Iz 7, 14). Chrystus posiada jednak twarz i proporcje ciała charakterystyczne dla mężczyzny w średnim wieku, co ma podkreślać Jego duchową dojrzałość ${ }^{105}$. Na ikonie „Trójcy” Nowotestamentowej ukazuje się różne relacje między Ojcem i Synem.

Przykładowo na ikonie zatytułowanej „Przedwieczna Narada” Bóg Ojciec i Syn Boży zdają się być pochłonięci dialogiem ${ }^{106}$. Jednak na niektórych przedstawieniach Chrystus może podchodzić do pustego tronu ${ }^{107}$. W zachodniej sztuce

\footnotetext{
99 Por. I. Jazykowa, Świat ikony, dz. cyt., s. 97.

${ }^{100}$ E. Smykowska, Ikona, dz. cyt., s. 80.

${ }^{101}$ I. Jazykowa, Świat ikony, dz. cyt., s. 98.

${ }^{102}$ K. Onasch, A. Schnieper, Ikony, dz. cyt., s. 144.

${ }^{103}$ Por. L. Balter, Pneumatologia ikony, dz. cyt., s. 85.

${ }^{104}$ K. Onasch, A. Schnieper, Ikony, dz. cyt., s. 135.

105 Tamże, s. 144.

106 Tamże, s. 145.

${ }^{107}$ E. Smykowska, Ikona, dz. cyt., s. 80.
} 
bardziej charakterystyczny był temat zwany „Tron Łaski”. Tutaj Bóg Ojciec zasiada na tronie i trzyma ukrzyżowanego Syna bądź to w ramionach lub na poziomie swych kolan ${ }^{108}$.

\section{WYOBRAŻENIA CHRYSTUSA POD POSTACIĄ ANIOŁA}

\section{Chrystus Święte Milczenie}

Tego typu wyobrażenie Chrystusa pod postacią anioła spotykane było bardzo rzadko, a bardziej popularne stały się dopiero w XIX w. w Rosji ${ }^{109}$. Tytuł takiego obrazu odwołuje się do proroctwa zawartego w księdze Izajasza: „Oto mój Sługa, którego podtrzymuję, Wybrany mój, w którym mam upodobanie. Sprawiłem, że Duch mój na nim spoczął. On przyniesie narodom Prawo. Nie będzie wołał ni podnosił głosu, nie da słyszeć krzyku swego na dworze" (Iz 42, 1-2).

Chrystus przedstawiony jest jako poważny, przyjmujący dostojną pozę anioł, który krzyżuje ręce na piersiach ${ }^{110}$. Posiada zamknięte usta, wyczuwa się w Nim ciszę i spokój. Wokół Jego głowy widoczny jest ciemny nimb. Zazwyczaj okrągły kształt tej otoczki wskazuje na wieczność i boskośćc11. Wewnątrz umieszczona jest gwiazda o ośmiu ramionach, w której na przemian powtarzają się dwa kolory ${ }^{112}$. Płomienna czerwień symbolizuje Bóstwo, natomiast ciemnozielona lub ciemnobłękitna barwa wskazuje na nieosiągalność i niepoznawalność boskiej istoty dla zmysłów śmiertelników ${ }^{113}$. Zestawienie błękitu i czerwieni może symbolizować też połączenie w Chrystusie dwóch natur: boskiej i ludzkiej. Ogólnie można powiedzieć, że dwie barwy, chociaż znacznie się różnią, to tworzą pewną jedność i często występują razem. Czerwień wielokrotnie oznaczała świat ziemski, a błękit niewidzialną rzeczywistość niebiańską. Zestawienie barw bordowej i błękitnej obecne było często na szatach Chrystusa. Dogmat Wcielenia, mówiący że prawdziwy Bóg stał się prawdziwym Człowiekiem został wyrażony właśnie za pomocą określonych środków artystycznych, a mianowicie dzięki zestawieniu obok siebie dwóch barw na zasadzie kontrastu ${ }^{114}$. Jeśli chodzi o wyobrażenie Chrystusa pod postacią anioła, to Zbawiciel może posiadać dość duże, przytłaczające skrzydła, na których widoczne są wyraźnie zaznaczone barwne pióra' ${ }^{115}$.

${ }^{108}$ K. Onasch, A. Schnieper, Ikony, dz. cyt., s. 144-145.

109 Tamże, s. 133.

${ }^{110}$ K. Onasch, A. Schnieper, Ikony, dz. cyt., s. 132-133.

111 Nimb (łac. obłok, chmura) - symboliczne wyobrażenie światłości otaczające głowę. Zazwyczaj jest okrągły lub przyjmuje formę promienistą. Ma na celu podkreślenie boskiej chwały (por. E. Smykowska, Ikona, dz. cyt., s. 55).

${ }_{112}$ K. Onasch, A. Schnieper, Ikony, dz. cyt., s. 132.

113 Na temat znaczenia barw w nimbie, zob. E. Smykowska, Ikona, dz. cyt., s. 55.

${ }^{114}$ I. Jazykowa, Świat ikony, dz. cyt., s. 35.

115 K. Onasch, A. Schnieper, Ikony, dz. cyt., s. 138. 


\section{Chrystus ukrzyżowany serafin (Dusza Chrystusa)}

Ogólnie wszystkie wyobrażenie ukrzyżowanego Jezusa Chrystusa pod postacią anielską stały się popularne zwłaszcza wtedy, kiedy trzeba było się przeciwstawić szerzącym się heretyckim poglądom bogumiłów ${ }^{116}$. Uważali oni, że Zbawiciel był istotą anielską a nie człowiekiem, nie mógł więc ponieść śmierci krzyżowej, bo Jego ciało nie podlegało cierpieniu i nie mogło być upokorzone ${ }^{117}$.

Temat ukrzyżowanego anioła w ikonografii ruskiej ukształtował się pod wpływem sztuki i mistyki zachodniej m.in. w oparciu o teksty opisujące stygmatyzację św. Franciszka z Asyżu († 1226) ${ }^{118}$. Tomasz z Celano w Traktacie o cudach św. Franciszka opisał wizję Biedaczyny z Asyżu, podczas której miał on zobaczyć Ukrzyżowanego Serafina. Święty podczas kontemplacji „ujrzał w widzeniu rozciągniętego nad sobą Serafina, wiszącego na krzyżu, mającego sześć skrzydeł, za ręce i nogi przybitego do krzyża. Dwa skrzydła unosiły się mu nad głową, dwa wyciągały do lotu, a dwa okrywały całe ciało. [...] Cieszył się z łaskawego wejrzenia, jakim Serafin patrzył na niego, ale przybicie do krzyża przeraziło go. [...] Otóż, podczas gdy szukając wyjaśnienia na zewnątrz, poza sobą, nie znalazł rozwiązania, nagle objawiło mu je w nim samym odczucie bólu"119.

W tym miejscu należy podkreślić, że serafiny oznaczały istoty niebiańskie posiadające ognistą naturę, a ich nazwę wywodzono od hebrajskich słów oznaczających „płonąć, palić się". Stąd też w ikonografii ukazywano je w barwie pomarańczowej lub jaskrawo czerwonej. Według Pseudo-Dionizego Areopagity stały one na szczycie hierarchii anielskiej wraz z cherubinami ${ }^{120}$. Ich wygląd został opisany przez proroka Izajasza: „Ujrzałem Pana siedzącego na wysokim i wyniosłym tronie, a tren Jego szaty wypełniał świątynię. Serafiny stały ponad nim; każdy z nich miał po sześć skrzydeł; dwoma zakrywał swą twarz, dwoma okrywał swoje nogi, a dwoma latał" (Iz 6, 1-2). W sztukach plastycznych te duchowe istoty wyobrażane były jako postacie z ciałami ludzkimi, ale w całości zakryte przez duże skrzydła. Jedna para skrzydeł unosząca się do góry zakrywała twarz, co miało wskazywać na to, że nie są oni godni patrzeć na Stwórcę. Druga para skrzydeł zakrywała ich ciała

116 Bogomili (bogomiłowie) - sekta ta powstała w Bułgarii w X w., łączyła elementy zaratustrianizmu (dualizm) z chrześcijaństwem, odrzucała hierarchię duchownych, władzę państwową, porządek społeczny oparty na zasadach feudalnych, byli przeciwnikami kultu świętych. Ponieważ sądzili oni, iż widzialny świat został stworzony przez Szatana, nie mogli uznać człowieczeństwa Chrystusa, a tym bardziej jego śmierci krzyżowej, która polegała na męczeństwie Jego ciała. Na temat bogumiłów, zob. D. Angelov, Bogomilstvo v Bolgarii, Moskwa 1904; G. Szwat-Gyłybowa, Bogomilstwo. Powieść elementarna, w: Haeresis bulgarica w bułgarskiej świadomości kulturowej, Warszawa 2005; T. Manteuffel, Historia powszechnia. Średniowiecze, Warszawa 2002, s. 136.

${ }_{117}$ K. Onasch, A. Schnieper, Ikony, dz. cyt., s. 138.

118 Tamże.

119 Tomasz z Celano, Traktat o cudach św. Franiszka z Asyżu 3C 4.

${ }^{120}$ E. Smykowska, Ikona, dz. cyt., s. 70 (por. P. O'Sullivan, Wszystko o aniołach, Gdańsk 2000). 
wraz z nogami, co oznacza, iż pozostawali oni niegodni, aby Stwórca ich widział. Za pomocą trzeciej, ostatniej pary skrzydeł unosili się w powietrzu, co miało im ułatwiać wypełnianie boskich misji ${ }^{121}$.

Kompozycja ukazująca Ukrzyżowanego serafina może nawiązywać do przedstawienia „Zbawiciela w majestacie”, jeśli chodzi o rozmieszczenie symbolicznych figur geometrycznych. W przedstawieniu, które popularnie nosi tytuł „Spas w siłach” czerwony „dolny” kwadrat oznaczał rzeczywistość ziemską, a błękitny owal wskazywał na sferę niebiańską ${ }^{122}$. Na jednej z ikon pochodzącej z kręgu moskiewskiego również cała scena umieszczona została na tle prostokąta o barwie czerwonej. Tak samo jak to było widoczne na wizerunku „Zbawcy w chwale”, na rogach tej figury umieszczone zostały symbole czterech ewangelistów. Czworokąt wydaje się być rozciągnięty a na jego powierzchni nałożony jest ciemny romb. W tym wypadku można go traktować jako odpowiednik błękitnego kręgu obecnego na przedstawieniu „Pantokratora w majestacie”. Dolny narożnik tego rombu wchodzi w głąb szczytu Golgoty, we wnętrzu której znajduje się czaszka pierwszego człowieka ${ }^{123}$. Te figury geometryczne stanowią tło dla postaci umieszczonych w centrum. Otóż najważniejszą rolę odgrywa tutaj Chrystus ubrany jak najwyższy arcybiskup (ros. archijerej). Z samej góry spływają na Niego promienie oznaczające obecność Trzeciej Osoby Boskiej. Zbawca ukazuje krzyż z ukrzyżowaną postacią, która prawie w całości przesłonięta jest przez olbrzymie skrzydła białego serafina. Jedynie widoczne są przebite dłonie i stopy wskazujące na śmierć krzyżową. Osoba rozpostarta na krzyżu jest w specyficzny sposób przesłonięta przez serafina, co sprawia wrażenie, że jej głowa należy też do anioła ${ }^{124}$.

Te wszystkie nowe tendencje w sztuce pojawiały się pod wpływem zachodnich trendów i przejawiały się właśnie w tworzeniu ikon Ukrzyżowanego anioła. Nie odpowiadały one jednak w pełni mentalności rosyjskiej i krytykował je m.in. diak Iwan Michałowicz Wiskowaty ${ }^{125}$.

\section{Ikona Sofii - Mądrości Bożej}

Mądrość (gr. Sophia, ros. Priemudrost) ${ }^{126}$ początkowo była rozumiana przez ludzi jako umiejętność typowo praktyczna, a dopiero później zaczęła odnosić się do sfery intelektualnej i kontemplacyjnej ${ }^{127}$. Sofia w ujęciu Ojców Kościoła zazwyczaj była interpretowana jako odbicie Mądrości Bożej i utożsamiona została z Logosem-Słowem Bożym, czyli Drugą Osobą Trójcy Świętej. Tradycja ta znana

${ }^{121}$ E. Smykowska, Ikona, dz. cyt., s. 70.

${ }^{122}$ I. Jazykowa, Świat ikony, dz. cyt., s. 80.

${ }^{123}$ K. Onasch, A. Schnieper, Ikony, dz. cyt., s. 139.

124 Tamże.

${ }^{125}$ I. Jazykowa, Świat ikony, dz. cyt., s. 85.

${ }^{126}$ E. Smykowska, Ikona, dz. cyt., s. 72.

${ }^{127}$ T. Špidlik, M. I. Rupnik, Mowa obrazów, dz. cyt., s. 123. 
była już od samego początku istnienia chrześcijaństwa ${ }^{128}$. Świadczą o tym także pierwsze zabytki sztuki bizantyjskiej (IV-V wiek) np. przedstawienie skrzydlatego Zbawiciela zachowane na ścianach katakumb Aleksandrii. O tym, że mamy tutaj do czynienia z mądrością świadczy grecka inskrypcja: „Sofia Jezus Chrystus" "29. Mądrość Boża, tak jak Chrystus zasiada na tronie niebiańskim i jest pełna niebiańskiego blasku, tak jak Syn Boży, który jest obrazem swego Ojca ${ }^{130}$.

Mądrość mogła być interpretowana na wiele sposobów i wyobrażano ją za pomocą wielu figur a zazwyczaj występowała w rodzaju żeńskim. Mogła być też utożsamiana z trzecią hipostazą Trójcy Świętej, Kościołem, Theotokos ${ }^{131}$, czy też stanowiła atrybut trójjedynego Boga. W księgach mądrościowych traktowana była jako zasada, według której stworzony został cały wszechświat, jako twórcza miłość Boskiego Kreatora i Jego odwieczna mądrość, która zawsze Mu towarzyszyła ${ }^{132}$.

W Starym Testamencie Mądrość wysławia siebie mówiąc: „Przed wiekami, na początku mnie stworzył, i po wiek wieków nie przeminę" (Syr 24, 9). W Księdze Mądrości o Sofii napisano: „Jest odblaskiem wiecznej światłości i nieskalanym zwierciadłem Boskiego działania oraz odbiciem Jego dobroci” (Mdr 7, 25); ,Jest ona wspanialsza od słońca i przewyższa wszystkie gwiazdy, a w porównaniu ze światłem - świeci jaśniej” (Mdr 7, 29).

Ikonograficzny temat „Mądrości” ukształtował się na podstawie tekstu z Księgi Przysłów: „Mądrość zbudowała sobie dom i wyciosała siedem kolumn, nabiła zwierząt, namieszała wina i stół zastawiła. Służące wysłała, by wołały z wyżynnych miejsc miasta: Prostaczek niech do mnie tu przyjdzie. Do tego, komu brak mądrości, mówiła: Chodźcie, nasyćcie się moim chlebem, pijcie wino, które zmieszałam. Odrzućcie glupote i żyjcie, chodźcie droga rozwagi!" (Prz 9, 1-6).

W Nowym Testamencie Sofia nie jest już mądrością bezosobową, ale ujawnia się personalnie w samym Chrystusie. W takim kontekście wypowiadał się św. Paweł w 1 Liście do Koryntian: „Natomiast tym, którzy są powołani zarówno spośród Żydów, jak i Greków, głosimy Chrystusa jako moc i mądrość Bożą". List do Hebrajczyków mówi o Synu Bożym, który często był utożsamiany z Bożą Mądrością: „On, jako odbicie ukazujące Jego chwałę i jako obraz Jego istoty, podtrzymuje wszystko swoim potężnym słowem. On dokonał oczyszczenia z grzechów i zasiadł w niebie po prawicy (Bożego) Majestatu” (Hbr 1, 3). „On jest obrazem Boga niewidzialnego - Pierworodnym wobec każdego stworzenia, bo w Nim zostało wszystko stworzone: i to, co w niebiosach, i to, co na ziemi, byty widzialne i niewidzialne, czy Trony, czy Panowania, czy Zwierzchności, czy Władze. Wszystko przez Niego

${ }^{128}$ Por. Florenski, Ikonostas i inne szkice, dz. cyt., s. 43; T. Špidlik, M. I. Rupnik, Mowa obrazów, dz. cyt., s. 124; K. Onasch, A. Schnieper, Ikony, dz. cyt., s. 140.

${ }^{129}$ E. Smykowska, Ikona, dz. cyt., s. 72.

${ }^{130}$ T. Špidlik, M. I. Rupnik, Mowa obrazów, dz. cyt., s. 124.

${ }^{131}$ E. Smykowska, Ikona, dz. cyt., s. 72.

${ }^{132}$ Tamże. 
i dla Niego zostało stworzone. On jest przed wszystkim i wszystko w Nim ma istnienie" (Kol 1, 15). Św. Jan Ewangelista utożsamia Słowo Boga z Jego Synem, dzięki któremu cały wszechświat zawdzięcza swoje istnienie: „Na początku było Słowo, a Słowo było u Boga, i Bogiem było Słowo. Ono było na początku u Boga. Wszystko przez Nie się stało, a bez Niego nic się nie stało, co się stało" (J 1, 1-3). Dlatego też Mądrość Bożą jako siłę stwórczą utożsamiano z Synem Bożym.

Można wyróżnić kilka typów ikonograficznych ukazujących Sofię, niemniej jednak najbardziej znaną kompozycję reprezentuje typ nowogrodzki z centralną postacią anioła ${ }^{133}$. Warto tu zaznaczyć, że w tradycji rosyjskiej Mądrość była rozumiana jako ożywcze tchnienie i wyobrażano ją sobie właśnie jako niewieścią lub anielską postać ${ }^{134}$. Ukazanie tutaj Anioła ma swoje nawiązanie do Księgi Izajasza, gdzie występuje „Anioł Wielkiej Rady”. Ten tytuł oznaczał zawsze Słowo Boże, które wcieliło się $\mathrm{w}$ widzialne ciało i zostało posłane do ludzi $\mathrm{z}$ określoną misją przez całą Trójcę Świętą ${ }^{135}$. W takim ujęciu mamy do czynienia z symbolicznym wyobrażeniem Chrystusa.

W Rosji wyobrażenia sofijne ukształtowały się w XIV-XV w. i charakteryzują się urozmaiconą symbolikąa ${ }^{136}$. Najbardziej typowa pod tym względem jest ikona pochodząca z Nowogrodu z 1500 roku. W centrum jej kompozycji na złotym tronie, bezpośrednio na poduszkach zasiada długowłosa postać anielska ubrana w szaty wskazujące na jej cesarską władzę i wszechpotęgę. Na drogocenną dalmatykę i omoforion nałożony jest złoty epitrachylion używany podczas korona$\mathrm{cji}^{137}$. Na głowie anioła wetknięta jest korona, która formą nawiązuje do zwieńczenia obronnego muru ${ }^{138}$, a całą głowę dodatkowo otacza jeszcze złoty nimb. Na uwagę zasługują tutaj wijące się wokół uszu i we włosach tasiemki-opaski. Noszą one nazwę „słuchy” (gr. pendition, ros. toroki lub stuchi) i mogą przybierać formę jednej wstążki umieszczonej nad czołem anioła i rozchodzącej się na boki. Toroki symbolizują czujny słuch aniołów na Boże polecenia i gotowość pokornego ich wypełniania ${ }^{139}$. Tron ma co prawda cztery główne podpory, ale także jeszcze podtrzymywany jest przez siedem ognistych kolumn - prętów $^{140}$, które symbolizują siedem darów Ducha Świętego ${ }^{141}$, siedem sakramentów, a także wskazują na niezachwianą siłę i trwałość panowania ${ }^{142}$. Lico anioła, dłonie oraz rozpostarte skrzydła są barwy

${ }^{133}$ P. Florenski, Ikonostas $i$ inne szkice, dz. cyt., s. 44-45.

${ }^{134}$ T. Špidlik, M. I. Rupnik, Mowa obrazów, dz. cyt., s. 123.

135 P. Evdokimov, Sztuka ikony, dz. cyt., s. 286.

${ }^{136}$ E. Smykowska, Ikona, dz. cyt., s. 72.

${ }^{137}$ Por. P. Florenski, Ikonostas i inne szkice, dz. cyt., s. 46; E. Smykow ska, Ikona, dz. cyt., s. 73; P. Evdokimov, Sztuka ikony, dz. cyt., s. 285.

${ }^{138}$ P. Florenski, Ikonostas i inne szkice, dz. cyt., s. 49.

139 Tamże; E. Smykowska, Ikona, dz. cyt., s. 62.

${ }^{140}$ Por. P. Florenski, Ikonostas $i$ inne szkice, dz. cyt., s. 46.

${ }^{141}$ P. Evdokimov, Sztuka ikony, dz. cyt., s. 285.

${ }^{142}$ E. Smykowska, Ikona, dz. cyt., s. 73. 
ognistoczerwonej ${ }^{143}$. Warto tutaj podkreślić, że czerwony kolor był często stosowany na obszarach północnej Rusi oraz w Nowogrodzie ${ }^{144}$. Skrzydła wskazują, że mamy do czynienia z istotą niebiańską, a ich jaskrawy kolor oznacza uduchowienie. Purpurowa barwa symbolizuje też przedwieczny świt, jaki panował jeszcze przed stworzeniem świata. Wtedy istniała tylko bezkształtna otchłań, z której Bóg stworzył byty istniejące wcześniej w jego zamyśle. Ta ciepła barwa zapowiada również światłość prawdziwego Słońca, czyli Słowa Bożego, gdy nastąpi Paruzja i powtórne Jego przyjście ${ }^{145}$. Barwa czerwona często symbolizowała też ognia Ducha ${ }^{146}$. Blask anioła tym bardziej rzuca się w oczy, dlatego że kontrastuje z ciemnym tłem, co nawiązuje do słów: „Światłość w ciemności świeci” (J 1, 5).

Sofia w jednej ręce dzierży królewskie berło, będące znakiem panowania, a w drugiej pergaminowy zwój, oznaczający samą treść i istotę Mądrości ${ }^{147}$. Kaduceusz (laska, rabdos) jest też symbolem zwierzchności nad duszami ludzkimi. Natomiast zwinięty zwój Pisma zostaje przyciśnięty do serca, czyli do miejsca, które sprawuje największą władzę w całym organizmie ${ }^{148}$.

Anioł kładzie swe stopy na twardym kamieniu, który może być interpretowany jako skała wiary, fundament Kościoła. Kolista forma kamienia wskazuje także na doskonałość i pełnię ${ }^{149}$. Cała figura Mądrości umieszczona jest w otoczeniu niebiańskich sfer, wpisana została bezpośrednio w ośmioramienną gwiazdę. Ta wielka gwiazda znajduje się na tle kręgów-pierścieni, zabarwionych na różne odcienie błękitu, a wewnątrz nich widoczne są złote mniejsze gwiazdy ${ }^{150}$. Mamy tutaj do czynienia z kosmicznymi sferami wyobrażającymi cały wszechświat, który w akcie twórczym zostanie powołany do istnienia przez Stwórcę ${ }^{151}$. Te elementy w jeszcze większym stopniu podkreślają aspekt kosmiczny i wszechwładzę Sofii nad światem. Błękitna barwa wskazuje na czystość nieba oraz rzeczywistość duchową, a z drugiej strony pobudza do kontemplacji ${ }^{152}$. Sfery przybierają formę kolistą, co ma też teologiczne uzasadnienie a kształt okręgu wskazuje na doskonałość wiecznej rzeczywistości, zdolnej do ciągłego odradzania się $e^{153}$. Symbolika kosmiczna pojawia się w różnych partiach na ikonie. Przykładowo odnosi się ona także do przedstawienia popiersiowego Chrystusa znajdującego się na samej górze ikony zaraz nad figurą Anioła. Z pewnością mamy tutaj do czynienia z Synem Bożym,

${ }^{143}$ P. Florenski, Ikonostas i inne szkice, dz. cyt., s. 46; Evdokimov, Sztuka ikony, dz. cyt., s. 285.

${ }^{144}$ I. Jazykowa, Świat ikony, dz. cyt., s. 33.

145 P. Evdokimov, Sztuka ikony, dz. cyt., s. 290-291.

${ }^{146}$ I. Jazykowa, Świat ikony, dz. cyt., s. 33.

${ }^{147}$ P. Evdokimov, Sztuka ikony, dz. cyt., s. 285.

148 P. Florenski, Ikonostas i inne szkice, dz. cyt., s. 48-49.

149 P. Evdokimov, Sztuka ikony, dz. cyt., s. 285.

${ }^{150}$ P. Florenski, Ikonostas $i$ inne szkice, dz. cyt., s. 46.

${ }^{151}$ P. Evdokimov, Sztuka ikony, dz. cyt., s. 290-291.

${ }^{152}$ P. Florenski, Ikonostas $i$ inne szkice, dz. cyt., s. 49.

${ }^{153}$ E. Smykowska, Ikona, dz. cyt., s. 73. 
o czym zaświadcza krzyżowy nimb. Otacza Go dodatkowo gwiazda, a na zewnątrz niej pierścień usiany gwiazdami ${ }^{154}$. Chrystus spuszcza ręce na dół wskazując tym samym na postać Sofii ${ }^{155}$, może też wykonywać gest błogosławieństwa ${ }^{156}$. Powyżej postaci Chrystusa ukazana jest rozwijająca się tęcza. Jest ona wypełniona wewnątrz gwiazdami, co również jest motywem kosmicznym. Tym bardziej ma to znaczenie, iż w centrum tej strefy znajduje się tzw. tron eucharystyczny ${ }^{157}$. Ten boski ołtarz określany także tronem przygotowanym zwiastuje paruzję i czeka na powtórne przyjście Syna Bożego. W języku greckim nosi nazwę hetojmazja (co oznacza „przygotowanie” a w rosyjskim ugotowannyj priesto $)^{158}$. Na tym złotym ołtarzu leży księga - Ewangelia oraz narzędzia męki, które wskazują na śmierć krzyżową i zapowiadają dokonanie się Eucharystii ${ }^{159}$.

Cała kompozycja wykazuje pewną analogię do schematu Deesis, gdyż głównej postaci asystują po obu jej stronach Jan Chrzciciel oraz Matka Boża. Theothokos w tym wypadku unosi na rękach Emmanuela ${ }^{160}$, przedstawia Go w okrągłym medalionie, co znaczy, iż ukazuje obraz preegzystującego Słowa, które istniało jeszcze przed swym wcieleniem oraz przed stworzeniem wszelkiego bytu. Zgadza się to z pierwszymi słowami Ewangelii św. Jana: „Na początku było Słowo” (J 1, 1). Widać więc, że wizerunek Zbawiciela powtarza się na jednej płaszczyźnie ikony i jest umieszczony w różnych jej miejscach. Sama postać anielska mogła mieć niekiedy głowę otoczoną nimbem krzyżowym oraz atrybuty wskazujące na Drugą Osobę Boską ${ }^{161}$. Co prawda przedstawienie Mądrości Bożej jest traktowane najczęściej jako symboliczne wyobrażenie Drugiej Osoby Boskiej, ale też spotyka się interpretacje, wedle których Sofia utożsamiana jest z Duchem Świętym. Jeśli przyjmie się za fakt, że Sofia to Słowo Boże, wówczas będziemy mieć do czynienia z powtórzeniem wizerunku Chrystusa na jednym obrazie.

Inną kompozycję sofijną reprezentuje typ jarosławski popularny między XVI a XVIII w. W centrum kompozycji umieszczone jest cyborium o sześciu kolumnach a $\mathrm{w}$ jego wnętrzu postawiono tron eucharystyczny. $\mathrm{Z}$ tym ołtarzem znajduje się krzyż z ukrzyżowanym Zbawicielem. Ten element równocześnie spełnia rolę siódmej kolumny ${ }^{162}$, a Chrystus jest najważniejszym filarem Kościoła. Tego typu wyobrażenia, w których Sofię interpretuje się jako odzwierciedlenie całego Kościoła, noszą też nazwę „Sofia z ukrzyżowaniem”163. Krzyż stanowi tu centrum,

\footnotetext{
${ }^{154}$ P. Florenski, Ikonostas i inne szkice, dz. cyt., s. 48.

155 P. Evdokimov, Sztuka ikony, dz. cyt., s. 285.

156 E. Smykowska, Ikona, dz. cyt., s. 73.

157 P. Florenski, Ikonostas i inne szkice, dz. cyt., s. 48.

${ }^{158}$ E. Smykowska, Ikona, dz. cyt., s. 30.

159 P. Florenski, Ikonostas i inne szkice, dz. cyt., s. 48.

${ }_{160}$ P. Evdokimov, Sztuka ikony, dz. cyt., s. 285.

${ }^{161}$ P. Florenski, Ikonostas $i$ inne szkice, dz. cyt., s. 50.

162 Tamże, s. 51.

${ }^{163}$ E. Smykowska, Ikona, dz. cyt., s. 73.
} 
któremu podporządkowane są inne elementy na ikonie, czyli wszystko to, co go otacza. Krzyż łączy świat stworzony z nadprzyrodzonym. W sztuce chrześcijańskiej motyw ten nie tylko obrazowo przedstawiał mękę Chrystusa, ale także niósł ze sobą bogatą sybolikę teologiczną. W jarosławskiej wersji mamy do czynienia z Sofią Krzyżową, która stanowi symbol Kościoła jednoczącego w sobie hierarchię niebiańską oraz ziemską ${ }^{164}$.

Wyobrażenie Sofii jest symboliczne, dlatego często wzbudzało pewne wątpliwości, tym bardziej że Sobór Trullański zabronił używania w sztuce symboli odnośnie Drugiej Osoby Trójcy Świętej już po akcie Wcielenia. Chodziło nie tylko o wyobrażenia baranka, czy ryby, ale także anioła ${ }^{165}$. Przedstawienia z Sofią odzwierciedlają cały boski plan i ekonomię zbawczą, zaczynając od wcielenia Syna Bożego, przechodząc przez jego śmierć i zmartwychwstanie a kończąc na ostatecznym Jego przyjściu w pełni chwały ${ }^{166}$. Mądrość to Boże Słowo, Jednorodzony Syn, przez którego i dzięki któremu wszystko powstało. To On przyjął ludzkie ciało, jak to pisał Jan Ewangelista: „Bogiem było Słowo” (J 1, 1), „Słowo stało się ciałem" ( $\mathrm{J} 1,14)$. Ikona ukazuje już przedsmak wieczności ${ }^{167}$. Ukazany jest tu ostateczny cel wszechświata, czyli jego całkowite przebóstwienie łącznie z człowiekiem. Są to czasy, kiedy nastąpi Królestwo Boże w pełni chwały ${ }^{168}$. Ten obraz zapowiada już blask Ósmego Dnia, promieniowanie chwały całego Trójosobowego Boga ${ }^{169}$. Centralny anioł zapowiada więc przyszłe Królestwo, w którym panować będzie Duch Święty ${ }^{170}$. Może być on interpretowany zarówno jako Druga, jak i Trzecia Osoba Trójcy. Przecież Duch Święty kontynuuje misję Syna Bożego po Jego Wniebowstąpieniu aż do Jego powtórnego przyjścia. Trzeba tutaj dodać, iż każda ikona wyraża sofijność stworzonego świata. Przedstawienie Sofii można traktować jako obraz samego Stwórcy ${ }^{171}$.

\section{PODSUMOWANIE}

Do symboliki biblijnej odwoływali się już pierwsi chrześcijanie, malując dość schematycznie znaki i przedstawienia, które pomimo swojej prostoty już od samego początku niosły ze sobą określoną głębszą treśćc ${ }^{172}$. Oczywiście trzeba podkreślić, że te najwcześniejsze wyobrażenia nie miały jeszcze rozbudowanego znaczenia teologicznego, można nawet powiedzieć, że cechuje je swoisty prymitywizm,

\footnotetext{
${ }^{164}$ Por. S. Bułgakow, Ikona i kult ikony, dz. cyt., s. 98.

${ }^{165}$ P. Evdokimov, Sztuka ikony, dz. cyt., s. 286.

166 E. Smykowska, Ikona, dz. cyt. s. 72.

${ }^{167}$ P. Evdokimov, Sztuka ikony, dz. cyt., s. 291.

168 Por. E. Smykowska, Ikona, dz. cyt., s. 73.

169 Por. P. Evdokimov, Sztuka ikony, dz. cyt., s. 291.

${ }^{170}$ P. Evdokimov, Sztuka ikony, dz. cyt., s. 291.

${ }^{171}$ Por. S. Bułgakow, Ikona i kult ikony, dz. cyt., s. 99.

172 Por. I. Jazykowa, Świat ikony, dz. cyt., s. 24.
} 
jeśli chodzi przesłanie alegoryczno-symboliczne ${ }^{173}$. Ewolucja sztuki była jednak czymś nieuniknionym, a schematy ikonograficzne coraz bardziej się urozmaicały, co widać zwłaszcza w czasach nowożytnych. Oczywiście ważne jest, że już od samego początku swego istnienia każda ikona posługuje się językiem symboli; tylko w ich kontekście może być odczytywana i sama działa jak symbol. Nie musi posługiwać się ona iluzją, by wprowadzić wiernych do duchowej rzeczywistości, lecz to co niewidzialne wyraża przez odpowiednie zestawienie znaków i formę artystyczną ${ }^{174}$. Nigdy nie może być ona naturalistyczna, bo nie odzwierciedla widzialnego świata, lecz posiada emblematyczną naturę ${ }^{175}$. Właśnie dlatego, że przekazuje dogmat, stanowi wizję niewidzialnego świata. Staje się przez to widzialną Ewangelią, bo to, co Pismo Święte przekazuje za pomocą litery, ona ukazuje obrazem ${ }^{176}$. Ten obraz odczytuje się jak tekst i niesie on ze sobą określony przekaz skierowany do osoby kontemplującej ikonę $e^{177}$.

Jeśli chodzi o symboliczne wyobrażenia Chrystusa, jakie pojawiały się w czasach nowożytnych, a zwłaszcza na obszarach Rusi, to wymagają one dogłębnej analizy, właśnie ze względu na wyjątkowo urozmaicony schemat ikonograficzny. Przy ich omawianiu trzeba się liczyć z wielością interpretacji, a dotyczy to zwłaszcza wyobrażeń Chrystusa pod postacią anioła. Nie zawsze wiadomo dokładnie czy mamy do czynienia z samym Chrystusem, czy też z Trzecią Osobą Trójcy Świętej, jak to występowało na ikonie Sofii Mądrości Bożej. Ikony tego rodzaju w jeszcze większym stopniu niż przedstawienia portretowe i dosłowne wyrażały ekonomię zbawczą, jaka stała się udziałem całej Trójcy Świętej. Cały zaś proces odkupienia ludzkości rozpoczął się już w akcie Wcielenia w łonie Bogurodzicy, co odzwierciedla ikona „Znaku” z wyobrażeniem Emmanuela - przedwiecznie istniejącego Słowa Bożego. Zapowiedź przyszłej męki Chrystusa uwidacznia się w schemacie ikonograficznym „Czuwające Oko Chrystusa”, gdzie niekiedy umieszczani są aniołowie $\mathrm{z}$ atrybutami męki krzyżowej. Ikona ta także zapowiada przyszłe zmartwychwstanie Zbawiciela, który nieustannie czuwa i troszczy się o ludzkość. Ważny jest również fakt, że schemat „Czuwające Oko” czy też Chrystus ukazany jako Baranek Boży (Cząstka Prosfory) ściśle wiążą się z rytami liturgicznymi, jakie dokonywane są w trakcie proskomidii. Ikonografia tutaj w pewien sposób odzwierciedla układ cząstek prosfory na diskosie. Godne uwagi są także wyobrażenia Chrystusa w przedstawieniach całej Trójcy Świętej. W Trójcy typu Starotestamentowego ukazany jest On jako jeden z trzech aniołów, a w Trójcy typu Nowotestamentowego pod postacią dojrzałego mężczyzny w szatach błękitno-czerwonych wskazujących na jego dwie natury.

\footnotetext{
${ }^{173}$ S. Bułgakow, Ikona i kult ikony, dz. cyt., s. 12.

174 Por. I. Jazykowa, Świat ikony, dz. cyt., s. 22.

175 Por. S. Bułgakow, Ikona i kult ikony, dz. cyt., s. 45.

176 Por. P. Evdokimov, Prawosławie, dz. cyt., s. 280.

177 Por. T. Špidlik, M. I. Rupnik, Mowa obrazów, dz. cyt., s. 20.
} 
Te wszystkie wyobrażenia są znacznie urozmaicone i niosą bogate treści teologiczne, co je zdecydowanie odróżnia od pierwszych symboli chrześcijańskich. A wiele $\mathrm{z}$ nich głębiej wniknęło w świadomość religijną dzięki rozwojowi rytów liturgicznych.

\section{MODERN BYZANTINE AND RUSSIAN ICONS WITH SYMBOLIC IMAGES OF JESUS CHRIST AN EXPLANATION OF THEOLOGY AND CANON OF ICONOGRAPHY}

\section{Summary}

The article explains the iconographic scheme of symbolic representations of Christ, which were present in the Russian and Byzantine art. In comparison to the first characters used on the early these icons have theological content. They represent the whole process of salvation for mankind, and many of them associated with the liturgy. For example, images of Christ as a "Watchful eye" or as the Lamb of God refer to the rites performed during the initial part of the Liturgy. Also important are the images of Christ in the performances of the whole Trinity. The type of the Old Testament Trinity He is shown as one of the three angels, and New Testament Trinity in the form of a man in robes of blue and red. Distinct type of representation is the Son of God in the form of an angel. There is here such topics as: Christ the Holy Silence, Christ Crucified Seraph and Sophia-Wisdom of God.

Keywords

symbolism, iconography, Byzantine art, Christology, theology 
